\title{
Surface profiles and basal shear stresses of outlet glaciers from a Late-glacial mountain ice field in western Scotland
}

\author{
Peter W. ThORP \\ Department of Geography, Royal Holloway and Bedford New College, University of London, \\ Egham, Surrey TW20 OEX, England
}

\begin{abstract}
Surface and basal long profiles are reconstructed for 13 outlet glaciers that drained ice from a large ice field $(80 \mathrm{~km}$ by $120 \mathrm{~km})$ that formed in the western Grampians of Scotland during part of the Late-glacial period (c. 1400010000 years BP). Basal shear stresses are calculated at $5 \mathrm{~km}$ intervals along the central flowlines of the reconstructed outlet glaciers. Individual basal shear stresses for the outlet glaciers range from 10 to $204 \mathrm{kPa}$. Variations in calculated basal shear stresses within and between the glaciers are mainly explained by differences in bedrock topography, extending and compressional flow, and by differences in basal boundary conditions. Low basal shear stresses $(<53 \mathrm{kPa})$ calculated for the terminal zones of Creran, Menteith and Lomond glaciers are partly explained by the overriding of glaciomarine clays with inferred high pore-water pressures and a low yield strength that may have led to rapid basal sliding and thinning of the ice lobes.
\end{abstract}

\section{INTRODUCTION}

The surface profiles of Pleistocene valley glaciers, ice caps and ice sheets can be reconstructed if sufficient detailed field evidence is available to delimit their maximal horizontal and vertical dimensions. Such an exercise is possible for parts of a large mountain ice field (Fig. 1) that reached its maximum extent in western Scotland during the Loch Lomond stade, some time after 11000 years BP (Sissons, 1976; Sutherland, 1984a).

The reconstructed profiles enable basal shear stresses $\left(\tau_{\mathrm{b}}\right)$ to be calculated along flowlines of 13 outlet glaciers that radiate outwards from the main accumulation areas of the ice field. An analysis of the spatial variation in basal shear stresses along individual glacier flowlines enables inferences to be made relating to the palaeodynamics of the former outlet glaciers. Such data are complemented by comparisons made between reconstructed palaeo and theoretical ice-surface profiles. In addition, the inferred parameters of the former Scottish glaciers provide useful comparisons with data derived from similar-sized presentday ice masses in other areas, e.g. Svalbard (Dowdeswell, 1986) and Baffin Island (Holdsworth, 1973).

\section{FIELD EVIDENCE}

The location and extent of the former Late-glacial ice field in Scotland described in this paper are shown in Figure 1, together with flowlines of the 13 outlet glaciers that have

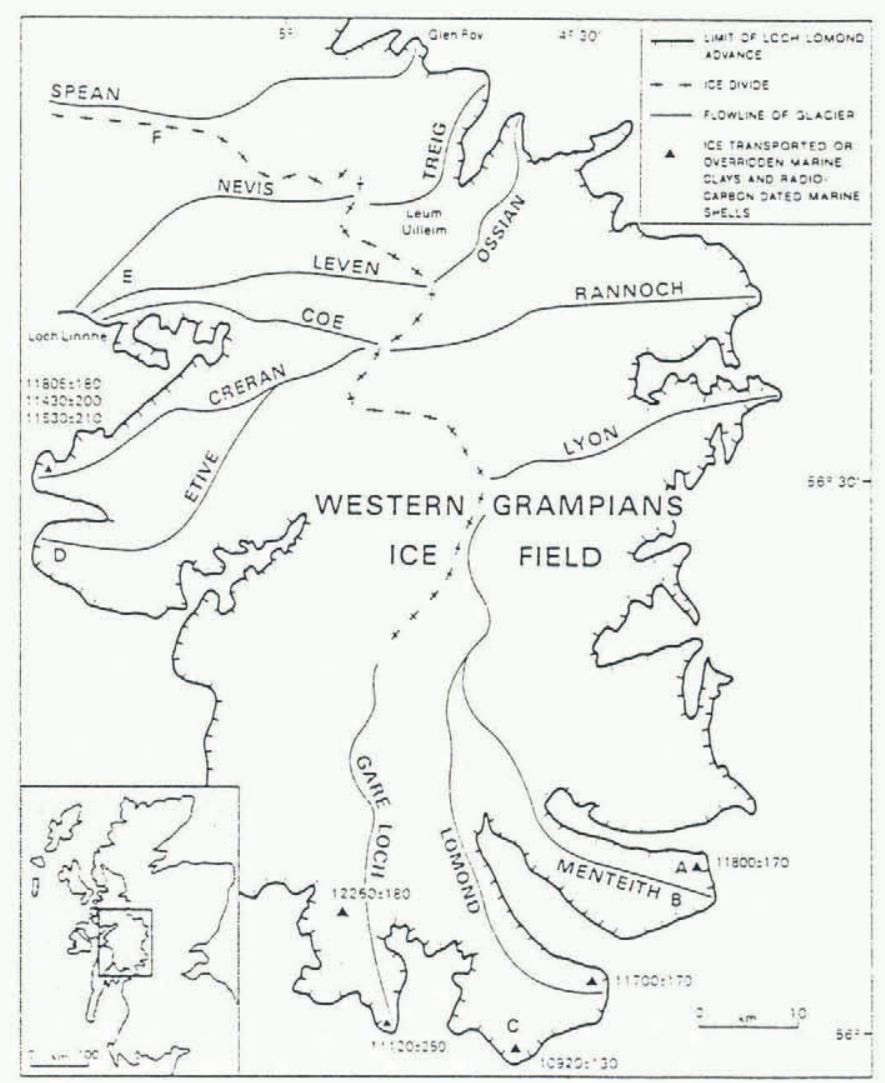

Fig. 1. The western Grampians ice field. Marine-shell dates after Peacock (1971) and Sutherland (1984a). For explanation of letters $A$ to $F$, see Table 1 . 
been reconstructed to obtain data for the calculation of basal shear stresses.

The maximal limits of seven of the glaciers are clearly defined by pronounced terminal moraines (e.g. Lomond, Menteith, Gare Loch, Ossian, Treig, Spean and Creran), and in most cases these are accompanied by lateral moraines that rise upvalley from the former snout. The maximal limits of the remaining outlet glaciers (i.e. Lyon, Rannoch, Nevis, Leven, Coe and Etive) are primarily determined by clear outwash land forms. The upper limits of the glaciers in their source areas are mainly defined by c. 240 inferred trim lines. These are identified by the upper limit of glacially smoothed bedrock or thick drift, or alternatively the lower limit of periglacially derived debris and frost-riven bedrock on valley spurs and around former nunataks (Thorp, 1984, 1986). The inferred trim lines form a spatial pattern, over an area exceeding $3000 \mathrm{~km}^{2}$, that is consistent with the interpretation that they relate to the Loch Lomond advance ice field (c. 11 000-10000 years $\mathrm{BP}$ ) and not to the earlier late Devensian ice sheet (c. 26000-13000 years BP). In a number of areas, Loch Lomond advance limits, based on lateral moraines rising upvalley towards the former accumulation areas, closely correspond in altitude with limits based on trim lines. For example, the highest lateral moraine formed at the margin of Ossian glacier is at an altitude of c. $670 \mathrm{~m}$. The altitude of trim lines (mapped before the lateral moraine was discovered) on nearby spurs and on a former nunatak (i.e. Leum Uilleim; Fig. 1) $2 \mathrm{~km}$ up-glacier of the lateral

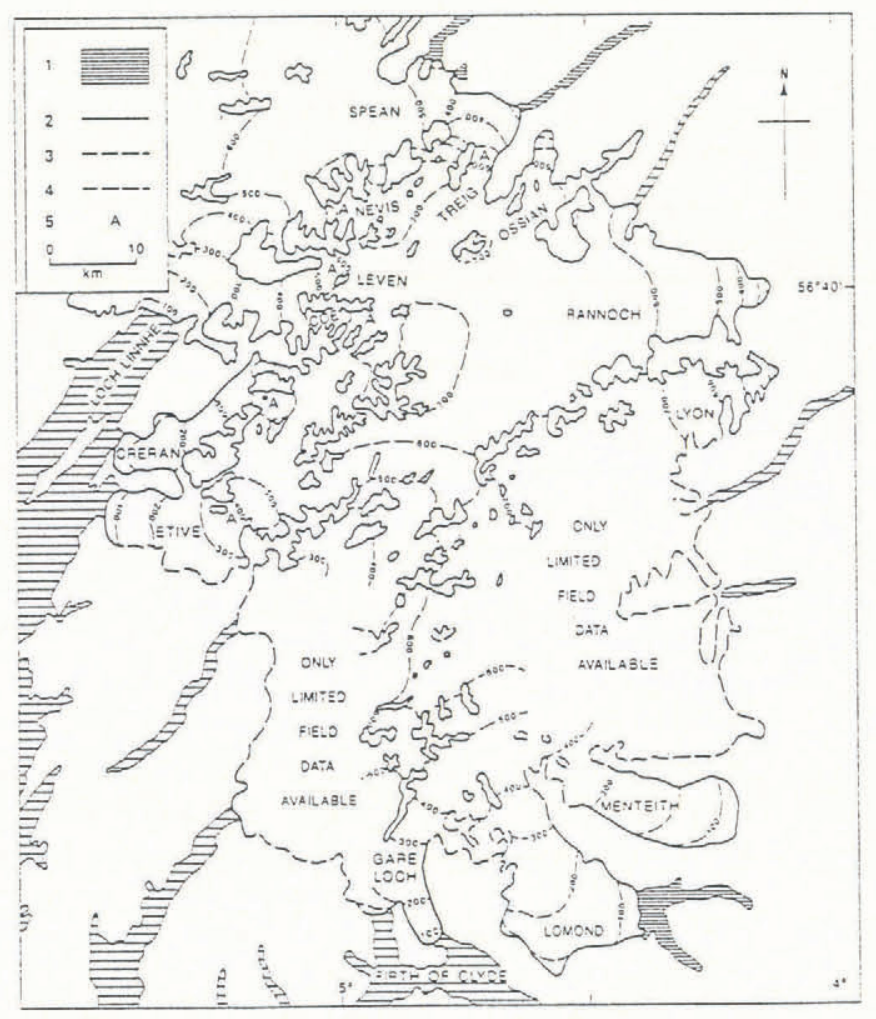

Fig. 2. Extent and surface form of the Loch Lomond advance ice field in the western Grampians. See Table 2 for sources used in the reconstruction of the ice field. (1) Ice-dammed lake; (2) Limit of Loch Lomond advance; (3) Limit uncertain; (4) Ice-surface contour at $100 \mathrm{~m}$ interval (not shown in cirques or narrow valleys); (5) Glacial breach mentioned in the text. moraine, range from c. 650 to $730 \mathrm{~m}$ (Thorp, 1986). It is therefore inferred that the moraines and the trim lines formed contemporaneously.

In all cases, basal shear stresses are calculated along flowlines extending from the snout to the principal ice shed. An area of uncertainty occurs at the head of Loch Lomond where only limited evidence is currently available to enable the upper limits of Menteith and Lomond glaciers to be determined (Fig. 2). The glacier surfaces in this area have been interpolated from reconstructed icesurface heights, based on field mapping of glacial and periglacial evidence, elsewhere in the southern part of the former ice field (Thorp, 1984).

\section{METHODS}

The flowlines of the 13 outlet glaciers (Fig. 1) were identified using ice-flow direction indicators (i.e. friction cracks, striae, roches moutonnées, erratic trains, and bedrock and drift streamlined by ice). The surface form of the ice field (Fig. 2) was reconstructed using the methods outlined by Thorp (1986). A surface concave down-glacier is assumed in the accumulation areas while a convex surface towards the snout is assumed on the lower ablation zone of each outlet glacier, except for the ice terminating in Loch Linnhe. Here the ice-surface contours were assumed to be concave, partly as a result of ice calving along a $3.5 \mathrm{~km}$ front and partly due to the local topography (see figure 2 of Brown and others (1982)). In many areas, contouring of the ice-field surface was facilitated by the spatial patterns of ice-flow direction indicators that indicated convergences and divergences of ice.

Measurements of the termini of 12 major grounded iceberg-calving glaciers in Alaska by Brown and others (1982) indicate that the mean height of the ice cliff above the water level ranges from 30 to $92 \mathrm{~m}$ with the height roughly a function of water depth (i.e. the deeper the water, generally the higher the ice cliff). Values of c. $60 \mathrm{~m}$ are assumed for the height of the ice cliff for Nevis, Coe, Leven and Spean glaciers that terminated in water deeper than $60 \mathrm{~m}$ (Figs 3 and 4). The height of the ice cliff for Etive, Creran, Gare Loch and Menteith glaciers, that terminated in water $10-30 \mathrm{~m}$ deep, is assumed to be c. $30 \mathrm{~m}$. From the above data and, as no floating-glacier termini are known in Alaska at the present time or in the recent past (Brown and others, 1982), none of the termini of the outlet glaciers of the Loch Lomond advance ice field is believed to have been floating. Surface and basal long profiles of the outlet glaciers were placed parallel to the inferred flowlines (Figs 3-5). Basal shear stresses were then derived from these data.

The main parameters that determine basal shear stresses are ice thickness and glacier-surface slope (Paterson, 1981). Thus, if it is assumed that ice behaves approximately as a perfectly plastic substance, the basal shear stresses of reconstructed glaciers can be calculated from the equation

$$
\tau_{\mathrm{b}}=\rho g h \sin \alpha
$$

where $\tau_{b}$ is the basal shear stress, $\rho$ is the mean ice density, 


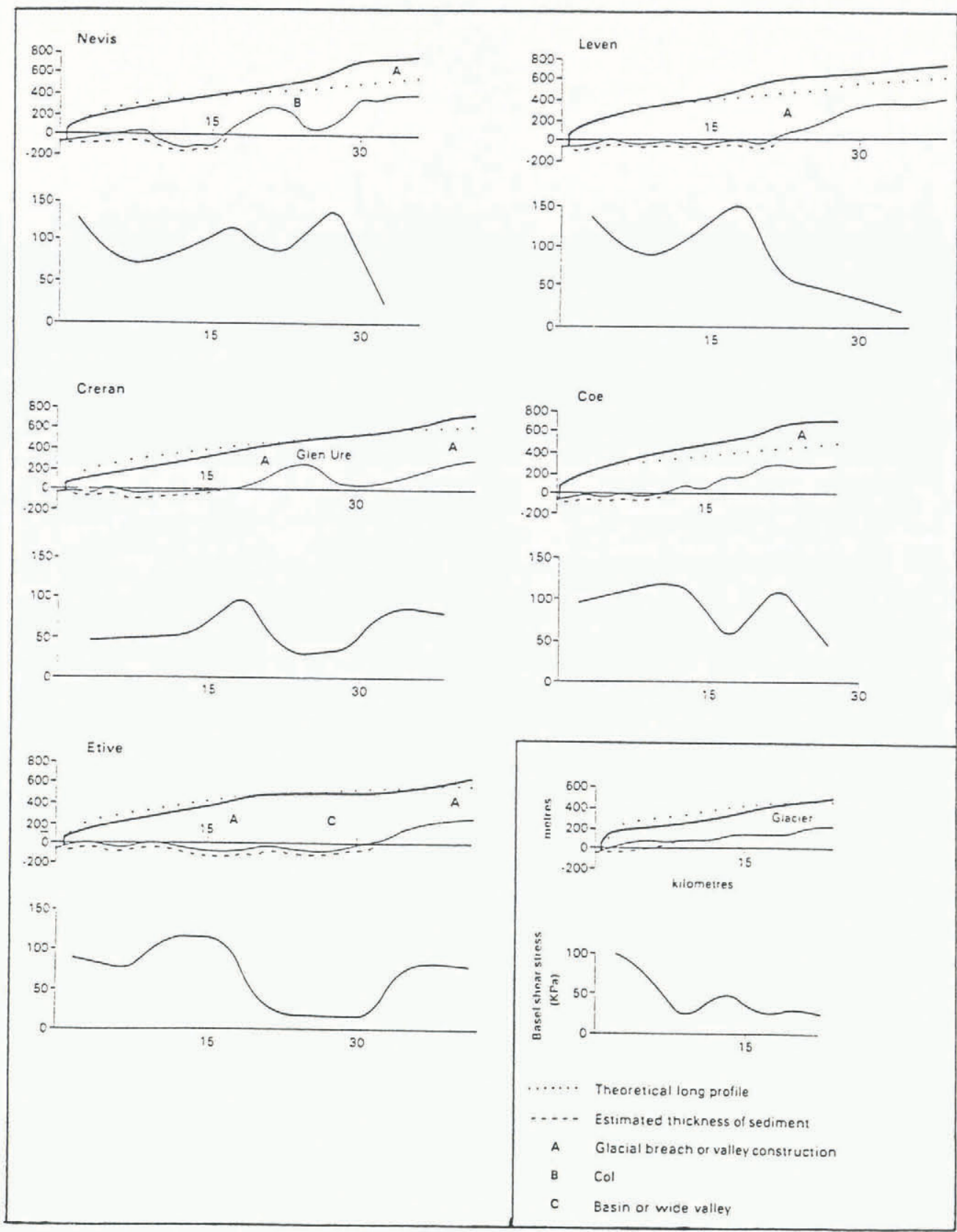

Fig. 3. Surface and basal profiles of the outlet glaciers west of the main ice shed and basal shear stresses.

$g$ is gravitational acceleration, $h$ is ice thickness and $\alpha$ is the ice-surface slope. The equation is best applied where the surface and bed slopes of the glacier are parallel (Nye, 1952a). Thus, the equation is less applicable to the termini of the outlet glaciers of the western Grampians ice field where the surface slope is inferred to have steepened as a result of either ablation or of calving into deep water.

\section{Errors}

The accuracy of reconstructed outlines of former glaciers is largely dependent on the type of field evidence available. Since ice thickness, which is one of the major parameters used for calculating basal shear stresses, is determined from the reconstructed glacier surfaces, errors in the interpretation of the field evidence will be reflected by inaccuracies in basal shear stresses. Below the ELA (equilibrium-line altitude), end and lateral moraines, drift limits and boulder limits can probably be used to define a former glacier margin to an accuracy of c. $10 \mathrm{~m}$ (Sutherland, 1984b). Above the ELA, ice-marginal evidence is usually less clear and largely dependent on the identification of trim lines. Thorp $(1984,1986)$ has estimated that trim lines can be used to define former glacier margins in the western Grampians to within 20$60 \mathrm{~m}$. In addition, cols and low mountain summits with clear glacial features, and cols and nunataks with periglacial evidence can be used to place constraints on the upper limits of the Loch Lomond advance glaciers. The accuracy of glacier-surface reconstructions above the ELA is also dependent on the number of control points (mainly trim lines) identified in the field (i.e. the reconstructed glacier outlines are likely to be most accurate where many control points are available).

In conclusion, calculated basal shear stresses are believed to be most accurate in the glacier terminal zones 


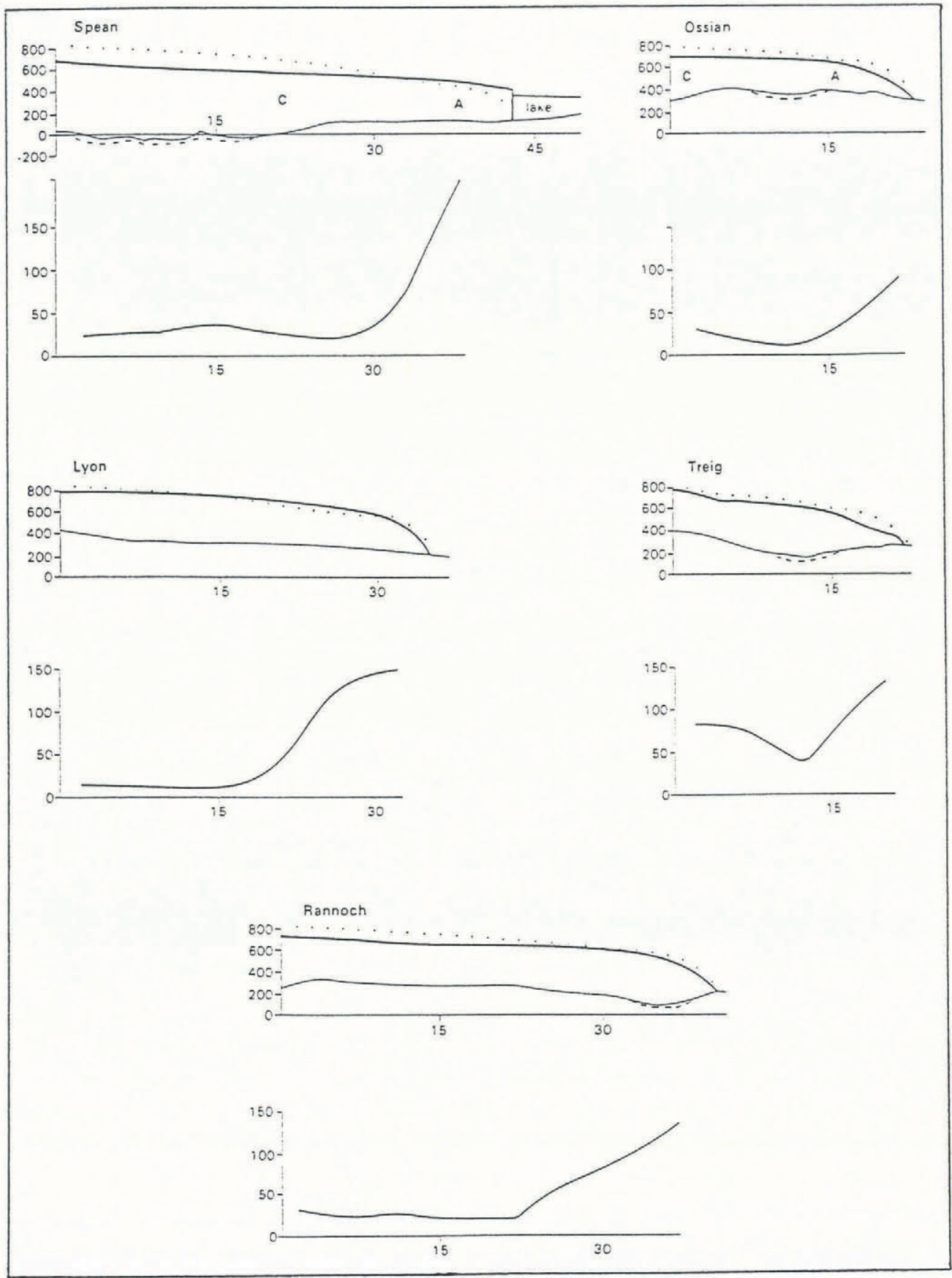

Fig. 4. Surface and basal profiles of eastward-flowing outlet glaciers and basal shear stresses.

with well-defined end and lateral moraines (e.g. Lomond, Menteith, Treig, etc.) and least accurate in the ice-source areas of the ice field, especially those areas with relatively few control points such as the southern central part of the ice field (Fig. 2). Estimated maximum inaccuracies of glacier-surface elevations above the ELA of $\pm 60 \mathrm{~m}$ would yield errors at worst $\pm 6 \mathrm{kPa}$ for gently sloping glaciers such as Lomond Glacier, while for steeply sloping glaciers such as Nevis Glacier errors would be $\pm 15 \mathrm{kPa}$.

Along Loch Linnhe and the Firth of Clyde (Fig. 2) is a prominent raised rock platform and cliff that Sissons (1979b) attributed to severe frost action assisted by wave action that occurred mainly during the cold climate of the Loch Lomond stade. Detailed levelling by Gray (1974) showed that the raised platform (Main Late-glacial Shoreline) is tilted down to the west, southwest and south away from the centre of glacio-isostatic uplift in the vicinity of Rannoch Moor with a regional tilt of $0.16 \mathrm{~m} \mathrm{~km}^{-1}$. Thus, it is necessary to consider the influence of glacio-isostatic uplift on the surface gradients of the outlet glaciers. Extrapolating the regional tilt of $0.16 \mathrm{~m} \mathrm{~km}^{-1}$ from Loch Linnhe to Rannoch Moor produces a vertical difference of c. 6-7 m betwee.1 the two areas. Since calculations show that a vertical difference of c. 6-7 m has a negligible influence on glacier-surface gradients, the effect of isostatic uplift is ignored here.

Basal shear stresses are affected by lateral and longitudinal variations in ice thickness and stress that are related to zones of extending and compressional flow in a glacier. These local variations are generally a response to bedrock irregularities in a steady-state glacier. Raymond 


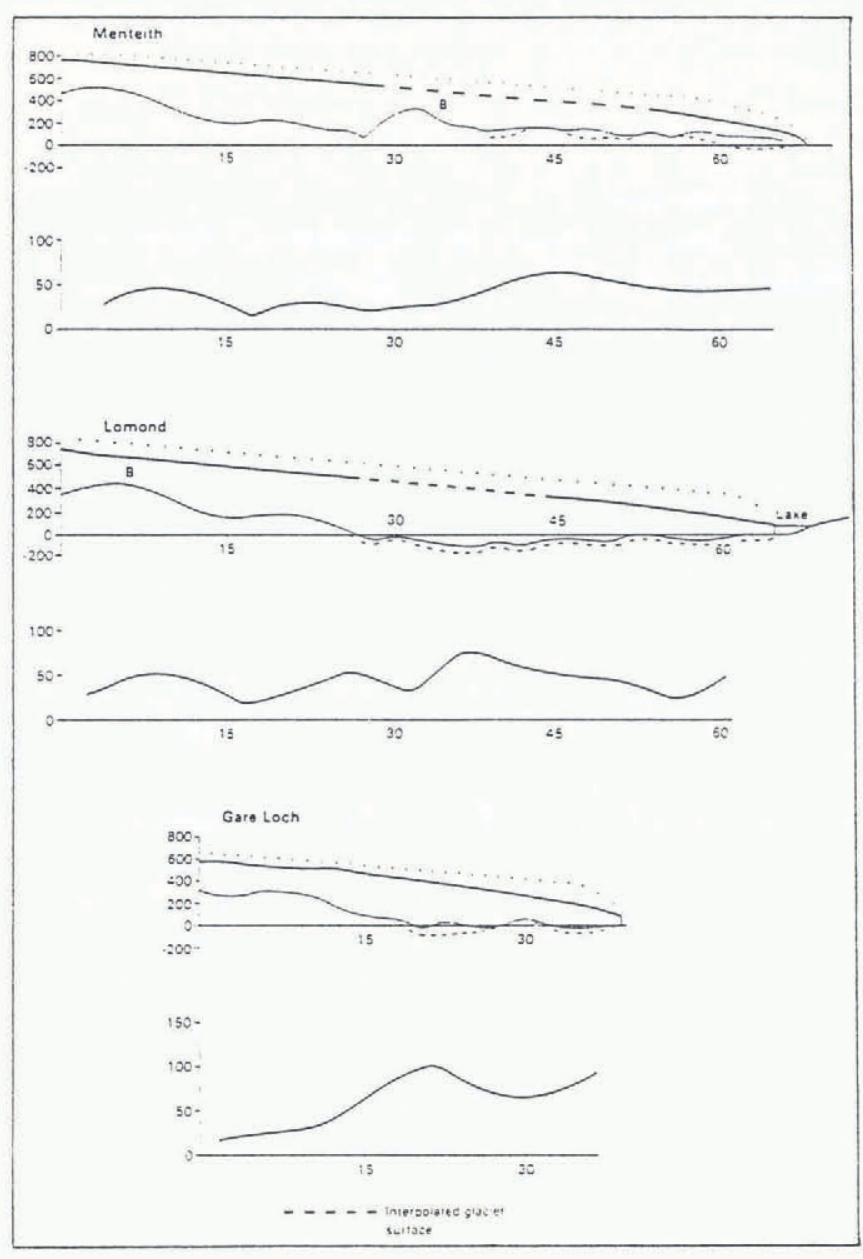

Fig. 5. Surface and basal profiles of southward-flowing outlet glaciers and basal shear stresses.

(1980) concluded that such fluctuations are minimized if the horizontal distance over which the surface slope is measured is $10-20$ times the ice thickness. Thus, where $h$ and $\alpha$ are averaged over horizontal distances of c. $10 h$ or more, the simple relation $\tau_{\mathrm{b}}=\rho g h \sin \alpha$ holds.

The influence of the frictional drag of the valley walls on the basal shear stresses of an outlet glacier also needs to be considered compared with an ice cap with no valley walls. Basal shear stresses will be inflated along the outletglacier centre line as a result of the valley walls supporting part of the weight of the glacier. Thus, a shape factor $F$ is introduced (after Nye, 1965) to modify Equation (1) where values of $F$ are calculated for different values of $W$ (half of width divided by thickness on centre line). Equation (1) becomes:

$$
\tau_{\mathrm{b}}=F^{\prime \prime} r g h \sin \alpha
$$

Values of $F$ for the reconstructed ice field considered in this paper range from 0.61 to 0.98 .

Many valleys and lochs within the limits of the western Grampians ice field contain substantial quantities of sediment. Only a few sites within the limits of the ice field contain organic material that has been radiocarbon dated as being earlier in age than the Loch Lomond stade (Sutherland, 1984a). All such sites lie just within the maximal limits of the outlet glaciers (Fig. 1; Table 1). The apparent lack of sediments older than the Loch Lomond stade elsewhere within the limits of the ice field suggest that the Loch Lomond advance glaciers removed most of any pre-existing sediments. The general absence of preLoch Lomond stadial sediments implies that the oulet glaciers were sliding over bedrock or over only small quantitites of basal debris for much of their length, except in their terminal zone. Such an assumption has been made in calculating the former thicknesses of the glaciers.

Along most valley floors, post-glacial incision by rivers into Late-glacial sediments has occurred down to the bedrock. As the great majority of the basal profiles are drawn along the lines of rivers that are usually parallel to former glacier flowlines, the thicknesses of sediments on valley floors are included when constructing the basal profiles. A more difficult problem to resolve is that of estimating thicknesses of sediments in sea- and fresh-water lochs in the western Grampians. These acted as sediment traps during deglaciation of the ice field and during the Holocene. Most of the outlet glaciers flowed along hollows now occupied by lochs, some of which extend for considerable distances (e.g. the $34 \mathrm{~km}$ long Loch Lomond). Data relating to the thicknesses of sediments in lochs within the limits of the Loch Lomond advance ice field are very sparse (Table 1; personal communication from the Institute of Geological Sciences, Edinburgh, 1986). However, since the values shown in Table 1 are likely to represent above-average thicknesses of sediment formed either at a glacier stillstand (e.g. the Corran Ferry outwash delta) or close to the maximum Loch Lomond

Table 1. Known thicknesses of sediments of inferred Lateglacial age in or near to lochs within the limits of the Loch Lomond advance ice field. The locations $A$ to $F$ are shown in Figure 1

\section{Thickness Sediment types Location References}

m

30 Sands
A. Drymen,
Sissons, 1967
Loch Lomond

42 Sands, silts and clays

53

$>60$

c. 40
Sands, gravels and clays
Sands and gravels

Sands and
gravels

Sands and
gravels

Diamicton

\section{B. Kilmaronoch, Elliott, 1984} Loch Lomond

C. Balloch, Loch Lomond

Browne and Graham, 1981

Gray, 1975
D. Achnacree,

E. Corran Ferry, Bailey and Loch Linnhe Maufe, 1960

F. Annat, Loch Eil

Peacock, 1970

Mouth of Loch Nevis, western Inverness-shire
Boulton and others, 1981 
advance limit, as for example at Balloch where the Lomond glacier overrode thick $(>40 \mathrm{~m})$ Late-glacial marine clays (Browne and Graham, 1981), an assumed average thickness of $50 \mathrm{~m}$ of sediment has been used in constructing the basal profiles along the lochs (Figs 3-5). The estimated value of $50 \mathrm{~m}$ is believed to be a reasonable approximation to the actual average thickness of sediment in the lochs. Furthermore, calculations of basal shear stresses were made both including and excluding estimated sediment thicknesses in the lochs within the limits of the Loch Lomond advance ice field. Such calculations show that the mean basal shear stress for all 13 glaciers only increases by $4 \mathrm{kPa}$ when the estimated mean sediment thickness of $50 \mathrm{~m}$ in the lochs is included. In this paper all references to basal shear stresses will henceforth relate to calculations that include the estimated $50 \mathrm{~m}$ of sediment.

\section{RESULTS}

Surface slope and ice thickness were averaged over distances of $5 \mathrm{~km}$ along the flowlines (Fig. 1) and basal shear stresses calculated using Equation (2). As most of the ice thicknesses used in the calculations are less than c. 500 $600 \mathrm{~m}$ (Table 2), it is argued here that the use of a horizontal distance of $5 \mathrm{~km}$ is valid and that most of the local variations in longitudinal stress are likely to be reduced significantly (Raymond, 1980). The basal shear stresses range from 10 to $204 \mathrm{kPa}$. The values calculated at $5 \mathrm{~km}$ intervals are shown in Figures 3-5.

\section{SURFACE PROFILES AND BASAL SHEAR STRESSES OF THE ICE FIELD}

The reconstructed ice-surface profiles are compared with profiles derived from glaciological theory (cf. Thorson, 1980; Dowdeswell, 1986) in order to study the difference in behaviour of the 13 outlet glaciers. Marked differences between reconstructed and theoretical profiles allow inferences to be made about the palaeodynamics of the Loch Lomond stadial ice field.

\section{Theoretical steady-state long profile}

Since there is only very limited information currently available for the mass balances and thermal regimes of the former outlet glaciers, it is considered preferable to use a relatively simple glaciological model, in which ice is assumed to be perfectly plastic (e.g. Nye, 1952b). The icesurface profile of such an ice mass can be approximated from:

$$
h=\left(2 h_{0}\right)^{1 / 2}(R-r)
$$

where $h$ is the ice thickness, $R$ is the ice-mass radius and $r$ is the distance from the centre of the ice mass. The term $h_{0}$ is given by

$$
h_{0}=\tau_{\mathrm{b}} / \rho g
$$

in which $\tau_{b}$ is the basal shear stress, $\rho$ is the mean ice
Table 2. Mean basal shear stress, basal slope and maximum thickness of outlet glaciers

Mean basal
shear
stress Basal slope Maximum ice Sources

\begin{tabular}{|c|c|c|c|c|c|}
\hline Nevis & 81 & 88 & 14 & 510 & Thorp, 1986 \\
\hline Leven & 74 & 83 & 11 & $590^{3}$ & $\begin{array}{l}\text { Thorp, 1981a, } \\
1986\end{array}$ \\
\hline Coe & 80 & 85 & 12 & 460 & $\begin{array}{l}\text { Thorp, 1981b, } \\
1986\end{array}$ \\
\hline Creran & 55 & 57 & 6 & 515 & $\begin{array}{l}\text { Peacock, 1971; } \\
\text { Gray, 1975; } \\
\text { Thorp, } 1986\end{array}$ \\
\hline Etive & 57 & 64 & 6 & $580^{3}$ & $\begin{array}{l}\text { Gray, 1975; } \\
\text { Thorp, } 1986\end{array}$ \\
\hline \multirow{2}{*}{\multicolumn{2}{|c|}{$\begin{array}{l}\text { Gare Loch } \\
\text { Anderson, }\end{array}$}} & 48 & 54 & 7.5 & $460^{3}$ \\
\hline & & & & & $\begin{array}{l}\text { 1949; Suther- } \\
\text { land, 1981; } \\
\text { Thorp, } 1984\end{array}$ \\
\hline Lomond & 40 & 45 & 6 & $620^{3}$ & $\begin{array}{l}\text { Sissons, 1967; } \\
\text { Thorp, } 1984\end{array}$ \\
\hline Menteith & 34 & 38 & 6 & 590 & $\begin{array}{l}\text { Sissons, 1967; } \\
\text { Thorp, } 1984\end{array}$ \\
\hline Lyon & 53 & 53 & 7 & 480 & $\begin{array}{l}\text { Thompson, } \\
\text { 1972; Thorp, } \\
1986\end{array}$ \\
\hline Rannoch & 40 & 46 & 1.4 & $430^{3}$ & $\begin{array}{l}\text { Thompson, } \\
\text { 1972; Thorp, } \\
1986\end{array}$ \\
\hline Ossian & 35 & 35 & 0 & $330^{3}$ & $\begin{array}{l}\text { Sissons, 1979a; } \\
\text { Thorp, } 1986\end{array}$ \\
\hline Treig & 78 & 82 & 6 & $500^{3}$ & $\begin{array}{l}\text { Sissons, 1979a; } \\
\text { Thorp, } 1986\end{array}$ \\
\hline Spean & 49 & 50 & -3 & $615^{3}$ & $\begin{array}{l}\text { Sissons, 1979a; } \\
\text { Thorp, } 1984\end{array}$ \\
\hline
\end{tabular}

$\mathrm{m} \mathrm{km}^{-1} \quad \mathrm{~m}$

Sources used in the glacier reconstructions listed:

${ }^{1}$ Calculated basal shear stresses excluding thickness of sediment in lochs are shown in column 2.

2 Calculated basal shear stresses including mean thickness of $50 \mathrm{~m}$ of sediment in lochs are shown in column 3.

${ }^{3}$ Calculated maximum thickness of ice does not include thickness of sediment on the loch floor. 
density and $g$ is gravitational acceleration. A yield stress of $50 \mathrm{kPa}$ is used in the equation, since this value is generally regarded as a reasonable one to use (see Paterson, 1981; Dowdeswell, 1986). Additionally, the adoption of a shear stress of $50 \mathrm{kPa}$ facilitates comparisons with glaciological data from other areas including New Zealand (Mathews, 1967), Puget Sound (Thorson, 1980) and Svalbard (Dowdeswell, 1986). If mean ice density is taken as $910 \mathrm{~kg} \mathrm{~m}^{-3}$, substitution into Equation (3) gives:

$$
h=3.35(R-r)^{0.5} \text {. }
$$

The model, however, rests on a number of assumptions (Paterson, 1981):

(i) The base of the ice mass is horizontal.

(ii) The bedrock is rigid.

(iii) Mass balance is uniform over the ice mass with flow more or less counterbalancing the effects of accumulation and ablation, resulting in a steady-state situation.

(iv) The ice is frozen to its bed.

(v) Temperatures, bed roughness and other factors, such as the presence of water at the ice/bedrock interface, that might influence the velocity of the ice mass are uniform throughout.

To what extent the above assumptions accord with conditions inferred for the reconstructed outlet glaciers of Loch Lomond stadial age will be discussed in a later section.

\section{Reconstructed ice-surface long profiles}

The reconstructed ice-surface profiles of the ice field can now be compared with a theroetical parabolic profile derived from Equation (4) using the method described by Drewry and Robin (1983) and Dowdeswell (1986).

The ice-surface profiles of Spean, Rannoch, Lyon and Ossian glaciers show a very close correspondence with the theoretical profile, particularly if flattening of the parabolic profile is allowed for in the ice-shed area (Fig. 4). In contrast, the reconstructed ice-surface profiles of the upper parts of Nevis, Coe and Leven glaciers all occur well above the theoretical profile (Fig. 3). Conversely, the reconstructed surface profiles of Menteith, Lomond and Gare Loch glaciers, and to a lesser extent Creran and Etive glaciers, fall below the calculated steady-state profile (Figs 3-5).

\section{Basal shear stresses}

Analyses of patterns of basal shear stresses (driving stresses) across the Antarctic ice sheet (Cooper and others, 1982) and the Nordaustlandlet ice caps of Svalbard (Dowdeswell, 1986) show an increase from low values close to the ice sheds to relatively high values near the ice-cap margins. A similar pattern occurs across the Late-glacial ice field in the western Grampians with the lower values near to the ice shed with maximum values generally occurring in the last $5 \mathrm{~km}$ of the outlet glaciers (Figs 3 and 4).

However, a number of anomalous values distort the simple trend of increasing basal shear stresses towards the ice margins. First, the basal shear stresses fall to between 40 and $52 \mathrm{kPa}$ in the terminal zones of Creran, Menteith and Lomond glaciers, which is the reverse of the general trend. Secondly, basal shear stresses fluctuate considerably along the flowlines of Nevis, Leven, Coe and Etive glaciers (Fig. 3) in the cnetral part of each glacier and values range from a minimum of $14 \mathrm{kPa}$ (Etive) to a maximum of $140 \mathrm{kPa}$ (Leven). The possible factors responsible for the variations in basal shear stresses along the glacier flowlines are discussed below.

\section{INTERPRETATION OF ICE DYNAMICS OF THE WESTERN GRAMPIANS ICE FIELD}

Many variables can influence the dynamics of ice masses. Some of the variables that have been investigated in the field or discussed in theoretical terms include topography (McIntyre, 1985), glacier mass balance (Haefeli, 1961; Boulton and others, 1984), glacier thermal regime (Bull, 1957; Paterson, 1972), subglacial water (Bindschadler, 1983; Weertman and Birchfield, 1983), glacier surges (Meier and Post, 1969), bedrock roughness and permeability (Weertman, 1966; Boulton, 1972) and deformable sediments (Mathews, 1974; Boulton and Jones, 1979; Clayton and others, 1985). The possible influences of some of the variables cited above on the palaeodynamics of the reconstructed outlet glaciers are considered next.

\section{Thermal regime}

Widespread evidence of striated, polished rock surfaces and ice-moulded bed forms, relatively unaffected by frost action, exists within the limits of the Loch Lomond stadial ice field (c. 11 000-10000 years BP), particularly on valley floors and sides, but also on interfluves overrriden by ice. More limited areas of ice-smoothed bedrock occur outside the mapped Loch Lomond advance limits but such rock outcrops are commonly disrupted by severe frost action. Moreover, striae and friction cracks outside the limits are generally fewer in number compared with those on rock surfaces within the Loch Lomond advance limits (Thorp, 1981a) due to the longer period of weathering since the decay of the last Scottish ice sheet (i.e. since c. 13500 years $\mathrm{BP})$.

The abundance of features created by subglacial erosion processes suggests that the basal ice of the ice field was at pressure-melting point over the entire extent of the ice field, or over a very large part of it when it was at its maximal extent c. 10500 years BP. It is widely agreed that a warm-based glacier will flow with a smaller stress than a glacier frozen to its bed (Paterson, 1981) with rates of flow largely dependent on the thickness of the water layer at the ice/bed interface, bedrock roughness and the temperature of the ice. Bull (1957) interpreted low basal shear stresses $(<50 \mathrm{kPa})$ calculated for the ice sheet in central northern Greenland as relating to the base of the ice sheet being at pressure-melting point. The low values contrast with the mean basal shear stress of $88 \mathrm{kPa}$ calculated for the ice sheet in southern Greenland that is believed to be frozen to its bed (Nye, 1952b). Such an interpretation, it is argued, can probably explain the relatively low basal 
shear stresses calculated for the western Grampians ice field (Figs 3-5) that occurred largely as a function of the outlet glaciers sliding over their beds. However, the precise role played by pressurized subglacial water and bedrock roughness in rates of sliding (Bindschadler, 1983; Weertman and Birchfield, 1983) and in influencing the basal shear stresses of the former Scottish glaciers is unknown at the present time because of a lack of suitable data. It seems probable, though, that variations in both of these factors will also have influenced the ice thicknesses and surface gradients of the outlet glaciers in the western Grampians.

\section{Mass balances}

Reviews of studies of glacier mass balances (Paterson, 1981; Sutherland, 1984b) emphasize the differences in net balance gradients (the increase of net balance in millimetres per metre of altitude) between glaciers in maritime and those in continental environments. High accumulation-ablation rates characterize maritime glaciers while glaciers in a continental situation will have much lower accumulation-ablation rates. Such differences in net balance gradients might be expected to be reflected by maritime glaciers having steeper surface gradients than glaciers in continental environments, if all other factors were equal.

Studies by Bull (1957), Haefeli (1961) and Boulton and others (1984) suggest that different mass-balance characteristics across a large ice mass are relatively unimportant in determining surface slopes. This view has been supported by Weertman (1973), who has shown that ice velocity responds sensitively to any change in thickness caused by increased accumulation since a higher discharge of ice will take place to maintain the glacier's equilibrium. However, since the above conclusion may not apply to smaller ice masses, the possible influence of differing mass balances on the surface gradients of the western Grampian ice field is considered below.

Sissons (1980) used glacier firn-line altitudes calcu-

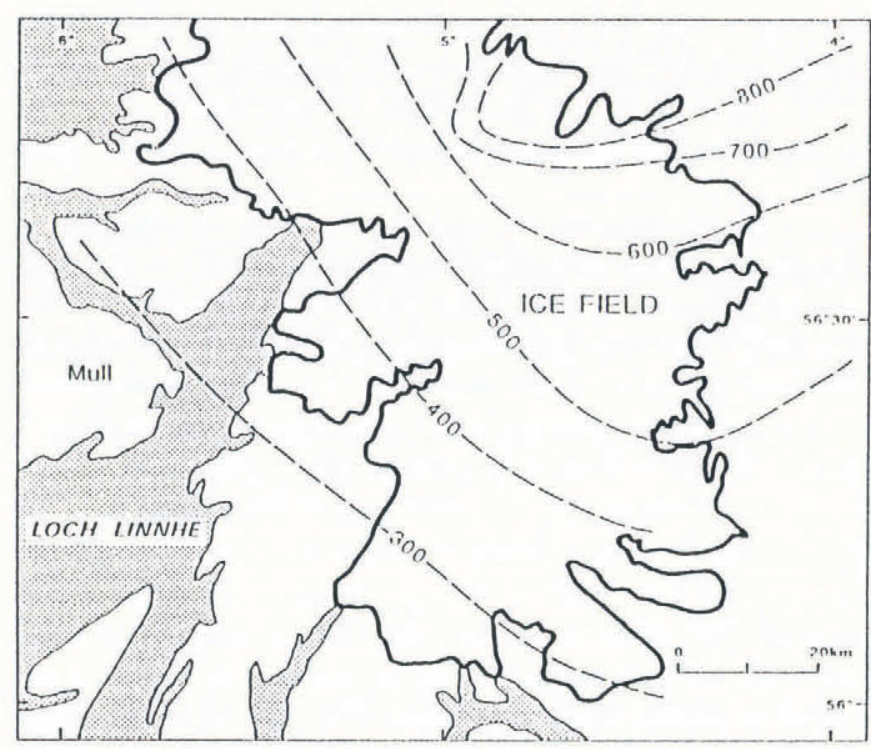

Fig. 6. Equilibrium firn-line altitudes for Loch Lomond advance glaciers in the western Grampians after Sissons (1979b). Altitudes in metres. lated for the Loch Lomond advance glaciers in the Scottish Highlands to estimate that the annual stadial precipitation on the mountains in the western Grampians was probably within the range $2700-4000 \mathrm{~mm}$ year $^{-1}$, but falling to as low as $500-600 \mathrm{~mm}^{-1} \mathrm{yer}^{-1}$ in the northwest Cairngorms. These spatial differences imply that precipitation during the Loch Lomond stade decreased in a southwest to northeast direction across the ice field. Such an inference is supported by the trend of the regional firnline altitudes across the western Grampians (Fig. 6) and by estimates of stadial precipitation decreasing from $c$. 3000 to 1800 mmyear $^{-1}$ in a southwest to northeast direction across the northern part of the western Grampians ice field (Thorp, 1984). Ablation rates too would have differed, being higher on the western than on the eastern side of the ice field due to aspect and due to the lower altitudes to which the outlet glaciers in the west descended. These contrasts in accumulation and ablation rates are inferred to have resulted in marked differences in glacier mass balances across the ice field with high accumulation-ablation rates in the southwest contrasting with lower accumulation-ablation rates in the northeast. Such mass-balance differences might be expected to be reflected by differences in basal shear stresses and icesurface gradients between glaciers on either side of the ice shed (i.e. more steeply sloping glacier sufaces in the west than in the east). It is apparent that a contrast does exist between the basal shear stresses and ice-surface profiles of the westward- and eastward-flowing glaciers in the northern half of the ice field, viz. Nevis, Leven, Coe, Creran and Etive glaciers have above-average basal shear stresses $(>60 \mathrm{kPa})$ and relatively steeply sloping surfaces while Lyon, Spean, Rannoch and Ossian glaciers are characterized by lower-than-average basal shear stresses $(<60 \mathrm{kPa})$ and gently sloping surfaces (Figs 3 and 4$)$. However, the southward-flowing glaciers (i.e. Gare Loch, Menteith and Lomond) that are inferred to have been high accumulation-ablation glaciers (Fig. 6) also have gently sloping surfaces and relatively low basal shear stresses (Fig. 7c). Therefore, from these data it seems unlikely that mass-balance differences between the outlet glaciers were of critical importance in influencing basal shear stresses and ice-surface gradients across the ice field. The other factors considered in this paper were probably of greater overriding importance in determining the calculated basal shear stresses shown in Figure 7.

\section{Topography}

The glaciers with the highest basal shear stresses and the steepest surface gradients are Nevis, Coe and Leven (Fig. 3). All three glaciers flowed westwards from water divides at altitudes of between 300 and $400 \mathrm{~m}$ on or close to Rannoch Moor and terminated in tidal water at a depth of c. $80 \mathrm{~m}$ in Loch Linnhe (c. 10500 years BP). These glaciers, therefore, descended the steepest topographic slopes $\left(>12 \mathrm{~m} \mathrm{~km}^{-1}\right)$ within the western Grampians ice field (Table 2). Hence, it seems reasonable to assume that their principal glaciological characteristics were strongly influenced by topography. Additionally, all three glaciers, together with Etive and Treig glaciers, show marked variations in surface gradients and yield stresses along parts of their lengths (Fig. 7a). 


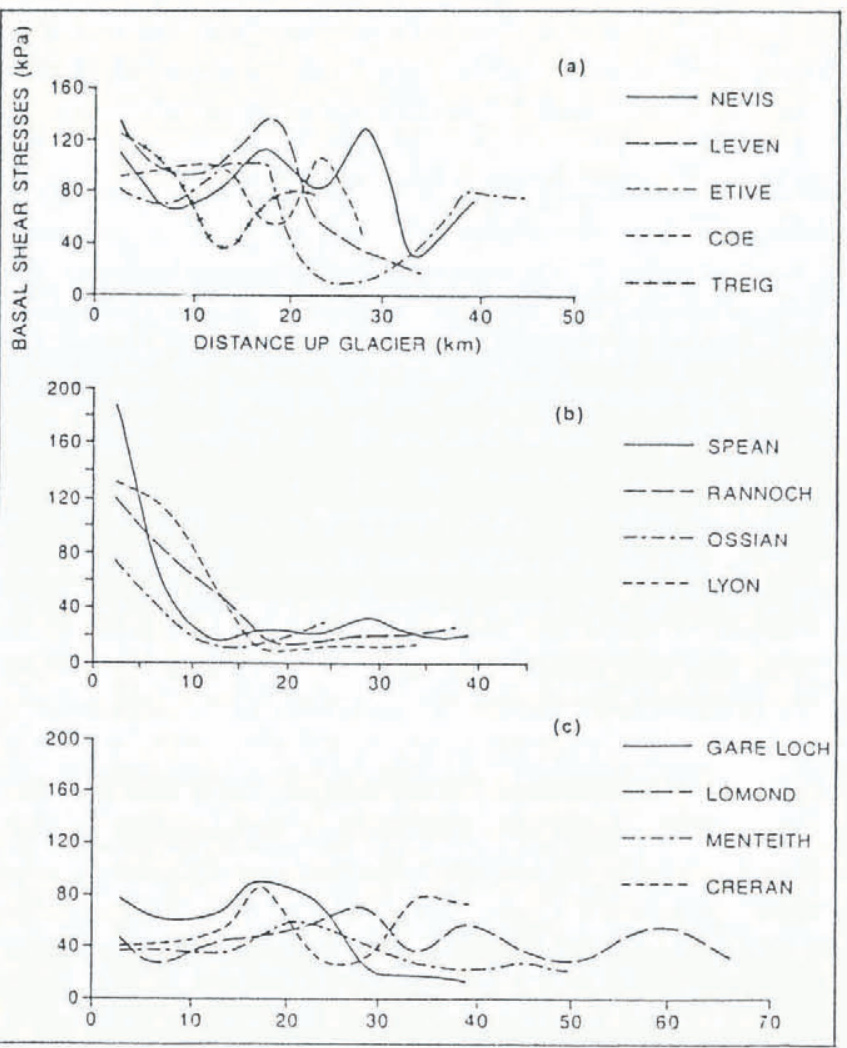

Fig. 7. Basal shear stresses along flowlines of former outlet glaciers in western Scotland. Basal shear stresses are averaged over $5 \mathrm{~km}$ intervals. (a) Outlet glaciers inferred to be strongly influenced by bedrock topography; (b) Outlet glaciers relatively unrestrained by bedrock topography; (c) Inferred continuously fast-flowing or surging glaciers.

High basal shear stresses $>95 \mathrm{kPa}$ occur in the vicinity of glacial breaches along the flowlines of Nevis, Etive, Treig, Leven, Coe and Creran glaciers (Figures 2, 3 and 4; Table 3). At each locality, the spatial pattern of striae, friction cracks and ice-moulded bed forms (Thorp, 1986) demonstrates that ice was converging towards a narrow glacial breach where a steepening of the ground surface generally occurs downvalley of the breach. Sharp drops in the altitude of the trim lines (Thorp, 1984) downvalley of

Table 3. Derived basal shear stresses for selected glacial breach sites (see Fig. 2)

$\begin{array}{ccc}\text { Glacier } & r_{\mathrm{b}} \text { excluding } & { }^{r_{\mathrm{b}} \text { including }} \\ \text { shape factor } & \text { shape factor }\end{array}$

$\mathrm{kPa} \quad \mathrm{kPa}$

\begin{tabular}{lllr} 
Nevis & 0.75 & 178 & 134 \\
Leven & 0.75 & 186 & 140 \\
Coe & 0.75 & 146 & 109 \\
Creran & 0.83 & 112 & 95 \\
Etive & 0.81 & 138 & 100 \\
Treig & 0.73 & 112 & 95 \\
\hline
\end{tabular}

some of the valley constrictions demonstrate a corresponding steepening of the glacier surface as the ice is inferred to have thinned and accelerated through the breach. Cooper and others (1982) have noted similar patterns of convergent ice flow and high basal shear stresses at the heads of outlet glaciers in Antarctica. The strong influence of the narrow glacial breaches on the surface gradients and velocities of the outlet glaciers at these locations is indicated by the calculation of relatively low shape factors and high basal shear stresses (Table 3). These data suggest that the averaging of surface slope and ice thickness over distances of $5 \mathrm{~km}$ is unlikely to have "smoothed" out all of the longitudinal stresses. Thus, the basal shear stresses calculated for parts of the steep outlet glaciers in the northern part of the western Grampians ice field are likely to be less reliable than the basal shear stresses calculated for other parts of the ice field.

The patterns of basal shear stresses along the flowlines of the eastward-flowing Spean, Rannoch, Lyon and Ossian glaciers provide striking contrasts with those of the glaciers to the west of the ice shed (Fig. 7a and b). The upper 15-30 km lengths of the four glaciers are characterized by low basal shear stresses $(10-32 \mathrm{kPa})$ and gently sloping surfaces. The former accumulation zones of all four glaciers are partly located in areas of low relief, comprising either wide valleys (e.g. Spean and Lyon) or basin areas (e.g. Rannoch and Ossian), that are characterized by horizontal or gently sloping bedrock surfaces (Fig. 4). The low basal shear stresses may, therefore, relate to the very gently sloping basal gradients $\left(<6 \mathrm{~m} \mathrm{~km}^{-1}\right)$ of the four eastward-flowing outlet glaciers in their accumulation areas (Fig. 7b). The low values calculated for Spean glacier (16-32 kPa) for much of its length may also reflect an additional factor, since it is the only one of the 13 outlet glaciers to advance up a reverse slope (Table 2; Fig. 4). It also terminated in the ice-dammed lake in Glen Roy (Fig. 4; Sissons, 1981), which may partly account for the anomalously high basal shear stress of $204 \mathrm{kPa}$ calculated for the last $5 \mathrm{~km}$ of the glacier.

The lower 10-15 km of Ossian, Rannoch and Lyon glaciers are also characterized by high basal shear stresses and steeply sloping surfaces (Fig. 7b), which contrast strongly with the low basal shear stresses that occur in their accumulation zones. Such patterns of basal shear stresses along flowlines are very similar to those described by Dowdeswell (1986) for outlet glaciers on Austfonna, Svalbard. Dowdeswell has explained the marked differences in shear stresses on Austfonna in terms of spatial differences in thermal regime with the glaciers frozen to their beds near their margins but possibly sliding near the centre of the ice cap. This explanation is unlikely to apply to the outlet glaciers of the western Grampians, for field evidence suggests that the Scottish glaciers were probably sliding to their margins. Instead, an alternative explanation is offered here in which it is suggested that topography may have been the major factor responsible for the high basal shear stresses in the lower zones of the four eastwardflowing glaciers. All four glaciers (Spean, Rannoch, Ossian and Lyon) flowed from wide valleys or basins towards narrow valley constrictions. For example, Rannoch glacier narrowed from $12 \mathrm{~km}$ in width, $20 \mathrm{~km}$ from its terminus, to less than $2 \mathrm{~km}$ close to its ice margin. Similarly, Spean glacier was over $10 \mathrm{~km}$ wide where is crossed the Great 
Glen but on its advance up Glen Roy it narrowed to only c. $1.5 \mathrm{~km}$. It is likely, therefore, that the narrow topographical outlets had the effect of "damming" up the ice to produce (in parts) the gentle ice surfaces in the accumulation areas and the steep ice surfaces where rock walls constrained the tongues of the four eastward-flowing outlet glaciers (cf. Drewry, 1983; Dowdeswell, 1986).

It has been noted (Dowdeswell, 1986) that basal shear stresses usually increase towards the glacier snout (Fig. 7). Yet, basal shear stresses for Lomond, Monteith and Creran glaciers are all below $53 \mathrm{kPa}$ within $5-15 \mathrm{~km}$ of the glacier snouts. One partial explanation of the low values is that all three glaciers terminated in shallow tidal water (c. 5-20 $\mathrm{m}$ deep) in the form of piedmont lobes. Such lobes formed where the outlet glaciers were no longer constrained by the steep bounding slopes of the mountains, allowing the ice to spread out radially and possibly to undergo thinning in a manner similar to Malspina Glacier in Alaska. However, other factors may have helped to create the low basal shear stresses calculated for the terminal zones of the three glaciers (see below), especially if it is noted that the Treig piedmont lobe has higher calculated values of 95 and $127 \mathrm{kPa}$ within $10 \mathrm{~km}$ of its terminus.

\section{Deformable sediments}

Although it has been suggested above that the lower-thanaverage basal shear stresses calculated for the piedmont lobes of Creran, Lomond and Menteith glaciers may reflect topographic influences, an additional factor may apply to these three glaciers as well as to Gare Loch glacier. The maximum limit of each glacier is indicated by a large arcuate end-moraine complex containing, in part, ice-transported clays and silts with marine bivalves (Fig. 1). The clays belong to the Clyde Beds that probably formed between c. 13500 and 10000 years BP in a predominantly glaciomarine environment during the retreat of the last Scottish ice sheet and during the advance of the Loch Lomond stadial glaciers (Peacock, 1981). Peacock envisaged deposition of the silts and clays by bottom traction currents and by turbid surface meltwater plumes in the vicinity of the ice fronts. Radiocarbon dating of the shells in the clays (Peacock, 1981; Sutherland, 1984a) confirms that the sediments are of Late-glacial age (Fig. 1). Peacock (1971), Sisson (1976) and Rose (1980) have noted that the clays have been glacitectonically disturbed and the shells crushed by the advancing ice lobes. It is suggested here that there is a casual link between the low basal shear stresses calculated for the four glaciers and the presence of glaciomarine clays. Mathews (1974), Boulton and Jones (1979), and Clayton and others (1985) have proposed that the very low equilibrium profiles of some of the lobes of the Laurentide (Wisconsin) ice sheet may have been caused by the overriding by ice of soft, easily deformable sediments with high pore-water pressures. Such an explanation is proposed for the terminal lobes of Creran, Lomond, Menteith and Gare Loch glaciers. These probably spread out and formed relatively low, flat sheets once the lobes were less constrained by topography and particularly when overriding of the marine clays commenced (Fig. 7).
The ice-flow regime outlined above is reflected by reconstructed long profiles below the theoretical steadystate profile derived from Equation (3), except for the upper $10 \mathrm{~km}$ of Creran glacier (Figs 3 and 5). Holdsworth (1973) and Dowdeswell (1986) have interpreted similar low ice-surface profiles, in conjunction with other glaciological data, for parts of the Barnes Ice Cap and Nordaustlandet ice caps, respectively, as indicating glaciers that have surged. Whether such an explanation for low ice-surface profiles can be applied to the Scottish outlet glaciers is unclear without further supporting evidence. If surges did occur within the ice field, it is not known whether the surges were confined to the lower parts of the outlet glaciers or whether whole outlet glaciers were affected. Nor is it clear, if surges or kinematic waves did occur above the ELA, how these may have affected the altitude of the trim lines identified in the field. Paterson (1981) has suggested that the down-glacier passage of waves of thickening associated with a surge front typically involves elevation changes of about $50 \mathrm{~m}$. Since most trim lines identified in the western Grampians are believed to be only accurate to within 20-60 m (Thorp, 1986), their degree of resolution is insufficient to distinguish between non-surging and surging glaciers. Furthermore, Dowdeswell (1986) used several lines of evidence, including low ice-surface profiles, to suggest that three southwardflowing outlet glaciers on Vestfonna, Svalbard, are fastflowing ice streams. Thus, since it is possible that the low surface profiles of Creran, Lomond, Menteith and Gare Loch glaciers reflect continuous fast sliding rather than a discrete surge (or surges), such a suggestion must remain tentative.

\section{CONCLUSIONS}

The variable patterns of calculated basal shear stresses and differing reconstructed ice-surface profiles along flowlines of the western Grampians ice field suggest that the outlet glaciers can be placed into three distinctive categories:

(1) Glaciers with steeply sloping ice surfaces and generally high basal shear stresses that descended relatively steep slopes to Loch Linnhe on the west side of the ice field, or to Loch Laggan in the case of Treig glacier. Marked fluctuations in basal shear stresses along parts of their lengths reflect the local topographical influence of narrow, steep-sided glacial breaches, through which the ice surface descended sharply. Unlike Creran glacier, the other westwardflowing glaciers do not appear to have been influenced by the possible presence of soft easily deformable sediments on the floors of the sea lochs. They are, therefore, interpreted as glaciers strongly influenced by the bedrock topography.

(2) The gently sloping surface profiles and patterns of basal shear stresses along the flowlines of the eastward-flowing Spean, Ossian, Rannoch and Lyon glaciers approximate very closely to a theoretical steady-state profile. The correspondence of reconstructed and theoretical profiles implies that the main morphological characteristics of these glaciers were largely derived from the rheological 
properties of ice. However, narrow, steep-sided valley constrictions at or near the ice margins of the four glaciers may have influenced the form of these particular glaciers when at their maximum limit. Nevertheless, it is inferred that the eastward-flowing glaciers were far less influenced by bedrock topography than those to the west of the main ice shed.

(3) Lomond, Menteith and Gare Loch glaciers, and the lower part of Creran glacier, are characterized by low basal shear stresses and reconstructed surfaces that generally lie well below the theoretical profile. Such relationships suggest that these glaciers may either have surged (perhaps repeatedly) or flowed fast continuously. If this interpretation is correct, the trigger mechanism for this behaviour may have been the advance of the four glaciers over soft marine clays with a low yield strength.

The interpretations of the varying patterns of basal shear stresses and ice-surface gradients of the Late-glacial ice field in western Scotland now need to be tested using additional data. In particular, work is needed on the relationships between the palaeoclimate of the western Grampians during the Loch Lomond stade and the inferred palaeodynamics and thermal regime of the ice field. For example, patterns of basal shear stresses and icesurface profiles similar to those described above have been calculated for inferred former "temperate" glaciers in New Zealand (Mathews, 1967), Puget Sound, U.S.A. (Thorson, 1980) and for present-day Vatnajökull, Iceland (Paterson, 1972). Such data might imply that the thermal regime of the western Grampians ice field was temperate. However, field evidence exists to suggest that the growth of the ice field was accompanied by severe periglacial conditions (summarized in Sissons (1979b)), resulting possibly in permafrost and with mean annual sea-level temperatures in the Scottish Highlands perhaps as low as $-8^{\circ}$ to $-10^{\circ} \mathrm{C}$ (Ballantyne, 1984). Clearly, it is unwise to assume, on the basis of currently available evidence, that the Late-glacial ice field had a temperate thermodynamic regime.

Finally, the reconstruction of the former mass balances, ice-temperature regimes and velocities of the outlet glaciers of the Late-glacial ice field, together with the data presented here, would greatly facilitate the understanding of the processes of formation of glaciogenic deposits within the limits of the ice field (Thorp, in press).

\section{ACKNOWLEDGEMENTS}

I am grateful to Drs J.A. Dowdeswell, J.J. Lowe, M.J. Sharp and D. G. Sutherland for kindly commenting on drafts of this paper. I thank G. Owen and J. Jacyno for drawing the maps and diagrams.

\section{REFERENCES}

Anderson, J.G.C. 1949. The Gare Loch Readvance moraine. Geology Magazine, 86, 239-244.

Bailey, E. B. and H. B. Maufe. 1960. The geology of Ben
Nevis and Glen Coe and the surrounding country. Mem. Geol. Surv. G.B.

Ballantyne, C. K. 1984. The Late Devensian periglaciation of upland Scotland. Quat. Sci. Rev., 3, 311-343.

Bindschadler, R. 1983. The importance of pressurized subglacial water in separation and sliding at the glacier bed. J. Glaciol., 29(101), 3-19.

Boulton, G.S. 1972. The role of thermal régime in glacial sedimentation. In Price, R.J. and D. E. Sugden, eds. Polar geomorphology. London, Institute of British Geographers, 1-19. (Special Publication 4.)

Boulton, G.S. and A.S. Jones. 1979. Stability of temperate ice caps and ice sheets resting on beds of deformable sediments. F. Glaciol., 24(90), 29-43.

Boulton, G.S., P.N. Chroston and J. Jarvis. 1981. A marine seismic study of late Quaternary sedimentation and inferred glacier fluctuations along western Inverness-shire, Scotland. Boreas, 10(1), 39-51.

Boulton, G.S., G.D. Smith and L. W. Morland. 1984. The reconstruction of former ice sheets and their mass balance characteristics using a non-linearly viscous flow model. J. Glaciol., 30(105), 140-152.

Brown, C.S., M.F. Meier and A. Post. 1982. Calving speed of Alaska tidewater glaciers, with application to Columbia Glacier. U.S. Geol. Surv. Prof. Pap. 1258-C.

Browne, M. A. E. and D. K. Graham. 1981. Glaciomarine deposits of the Loch Lomond Stade in the Vale of Leven between Dumbarton and Balloch, west-central Scotland. Quaternary Newsletter 34, 1-7.

Bull, C. 1957. Observations in North Greenland relating to theories of the properties of ice. J. Glaciol., 3(21), 6772.

Clayton, L., J. T. Teller and J. W. Attig. 1985. Surging of the south-western part of the Laurentide ice sheet. Boreas, 14(3), 235-241.

Cooper, A.P.R., N.F. McIntyre and G.deQ. Robin. 1982. Driving stresses in the Antarctic ice sheet. Ann. Glaciol., 3, 59-64.

Dowdeswell, J.A. 1986. Drainage-basin characteristics of Nordaustlandet ice caps, Svalbard. J. Glaciol., 32(110), 31-38.

Drewry, D.J. 1983. Antarctic ice sheet: aspects of current configuration and flow. In Gardner, R. and S. Scoging, eds. Mega-geomorphology. Oxford, Clarendon Press, 18-38.

Drewry, D. J. and G. de Q. Robin. 1983. Form and flow of the Antarctic ice sheet during the last million years. In Robin, G.de Q, ed. The climatic record in polar ice sheets. Cambridge, etc., Cambridge University Press, 28-38.

Elliott, C.J. 1984. Flandrian palynology and palaeoenvironments of the BGS mains of Kilmaronock borehole, Loch Lomond, Scotland. (M. Sc. thesis, City of London Polytechnic and Polytechnic of North London.)

Gray, J. M. 1975. The Loch Lomond Readvance and contemporaneous sea-levels in Loch Etive and neighbouring areas of western Scotland. Proceedings Geological Association, 86, 277-338.

Haefeli, R. 1961. Contribution to the movement and the form of ice sheets in the Arctic and Antarctic. 7. Glaciol., 3(30), 1133-1151.

Holdsworth, G. 1973. Evidence of a surge on Barnes Ice Cap, Baffin Island. Can. J. Earth Sci., 10(10), 1565-1574.

McIntyre, N.F. 1985. The dynamics of ice-sheet outlets. J. Glaciol., 31(108), 99-107. 
Mathews, W. H. 1967. Profiles of Late Pleistocene glaciers in New Zealand. N.Z. J. Geol. Geophys., 10(1), 146-163.

Mathews, W.H. 1974. Surface profiles of the Laurentide ice sheet in its marginal areas. F. Glaciol., 13(67), 37-43.

Meier, M. F. and A. Post. 1969. What are glacier surges? Can. 7. Earth Sci., 6(47), 807-817.

Nye, J.F. 1952a. A method of calculating the thicknesses of the ice sheets. Nature, 169(4300), 529-530.

Nye, J. F. 1952b. The mechanics of glacier flow. F. Glaciol., 31(108), 82-93.

Nye, J.F. 1965. The flow of a glacier in a channel of rectangular, elliptic or parabolic cross-section. 7 . Glaciol., 5(41), 661-690.

Paterson, W.S.B. 1972. Laurentide ice sheet: estimated volumes during Late Wisconsin. Rev. Geophys. Space Phys., 10, 885-917.

Paterson, W. S. B. 1981. The physics of glaciers. Second edition. Oxford, etc., Pergamon Press.

Peacock, J. D. 1970. Some aspects of the glacial geology of west Inverness-shire. Bull. Geol. Surv. G.B. 33, 43-56.

Peacock, J.D. 1971. Terminal features of the Creran Glacier of Loch Lomond Readvance age in western Benderloch, Argyll and their significance in the Lateglacial history of the Loch Linnhe area. Scott. J. Geol., 7, 349-356.

Peacock, J. D. 1981. Scottish Late-glacial marine deposits and their environmental significance. In Neal, J. and J. Flenley, eds. The Quaternary in Britain. Oxford, etc., Pergamon Press, 222-236.

Raymond, C.F. 1980. Temperate valley glaciers. In Colbeck, S. C., ed. Dynamics of snow and ice masses. New York, etc., Academic Press, 79-139.

Rose, J. 1980. Field guide to the Quaternary geology of the south-eastern part of the Loch Lomond basin. Proc. Geol. Soc. Glasgow, 3-19.

Sissons, J.B. 1967. The evolution of Scotland's scenery. Edinburgh, Oliver and Boyd.

Sissons, J. B. 1976. The geomorphology of the British Isles: Scotland. London, Methuen.

Sissons, J. B. 1979a. The limits of the Loch Lomond Advance in Glen Roy and vicinity. Scott. 7. Geol., 15(1), 31-42.

Sissons, J. B. 1979b. The Loch Lomond Stadial in the British Isles. Nature, 280(5719), 199-203.

Sissons, J. B. 1980. Palaeoclimatic inferences from Loch Lomond Advance glaciers. In Lowe, J.J., J. M. Gray and J. E. Robinson, eds. Studies in the Lateglacial of northwest Europe. Oxford, etc., Pergamon Press, 31-43.
Sissons, J. B. 1981. Ice-dammed lakes in Glen Roy and vicinity: a summary. In Neale, J. and J. Flenley, eds. The Quaternary in Britain. Oxford, etc., Pergamon Press, 174 183.

Sutherland, D. G. 1981. The raised shorelines and deglaciation of the Loch Long/Loch Fyne area, western Scotland. (Ph. D. thesis, University of Edinburgh.)

Sutherland, D. G. 1984a. Modern glacier characteristics as a basis for inferring former climates with particular reference to the Loch Lomond Stadial. Quat. Sci. Rev., 3, 291-309.

Sutherland, D. G. 1984b. The Quaternary deposits and landforms of Scotland and the neighbouring shelves: a review. Quat. Sci. Rev., 3, 157-254.

Thompson, K.S.R. 1972. The last glaciers in western Perthshire. (Ph. D. thesis, University of Edinburgh.)

Thorp, P.W. 1981a. An analysis of the spatial variability of glacial striae and friction cracks in part of the western Grampians of Scotland. Quaternary Studies (City of London Polytechnic and Polytechnic of North London) 1, 71-94.

Thorp, P.W. 1981b. A trimline method for defining the upper limit of Loch Lomond Advance glaciers: examples from the Loch Leven and Glen Coe areas. Scott. 7. Geol., 17(1), 49-64.

Thorp, P.W. 1984. The glacial geomorphology of part of the western Grampians of Scotland with especial reference to the limits of the Loch Lomond Advance. (Ph. D. thesis, City of London Polytechnic.)

Thorp, P.W. 1986. A mountain icefield of Loch Lomond Stadial age, western Grampians, Scotland. Boreas, 15(1), 83-97.

Thorp, P. W. In press. Western Grampians. In Ehlers, J., P. L. Gibbard and J. Rose, eds. Glacial deposits in Great Britain and Ireland. Rotterdam, Balkema.

Thorson, R. M. 1980. Ice-sheet glaciation of the Puget lowland, Washington, during the Vashon Stade (Late Pleistocene). Quat. Res., 13(3), 303-321.

Weertman, J. 1966. Effect of a basal water layer on the dimensions of ice sheets. J. Glaciol., 6(44), 191-207.

Weertman, J. 1973. Position of ice divides and ice centers on ice sheets. 7. Glaciol., 12(66), 353-360.

Weertman, J. and G. E. Birchfield. 1983. Basal water film, basal water pressure, and velocity of traveling waves on glaciers. 7. Glaciol., 29(101), 20-27.

The accuracy of references in the text and in this list is the responsibility of the author, to whom queries should be addressed. 